DOI

\title{
КЛІНІЧНІ ОСОБЛИВОСТІ НЕЕФЕКТИВНО ЛІКОВАНОГО ВПЕРШЕ ДІАГНОСТОВАНОГО ТУБЕРКУЛЬОЗУ ЛЕГЕНЬ ІЗ НАЯВНІСТЮ СТІЙКОСТІ ДО ПРОТИТУБЕРКУЛЬОЗНИХ ПРЕПАРАТІB
}

\author{
○Р. М. Ясінський ${ }^{1}$, А. М. Краснєвич² \\ 1 Запорізький державний медичний університет \\ ${ }^{2}$ КУ Міський протитуберкульозний диспансер № 4 ЗОР
}

РЕЗЮМЕ. Метою дослідження стало встановлення клінічних особливостей неефективно лікованого вперше діагностованого туберкульозу легень при наявності стійкості до протитуберкульозних засобів.

Матеріали і методи. Для досягнення мети проаналізовано 60 історій хвороб пацієнтів. Хворих було поділено на 2 групи: до 1 групи увійшли 25 осіб, у яких була встановлена резистентність до протитуберкульозних препаратів, та які не належали до 4 категорії хворих, до 2 групи увійшли 35 осіб, у яких зберігалася чутливість до всіх протитуберкульозних препаратів. Визначали статистичну значимість відмінностей між групами за допомогою критерію «х-квадратів», при кількості випадків менше 20 додатково користувалися правкою Єтса.

Результати. Тривалість захворювання до встановлення діагнозу туберкульозу становила 18,7 \% у хворих 1 групи та 7,4 \% - у 2 групи понад 3 місяці, p<0,05. Визначалася тенденція до більш поширених форм туберкульозу у пацієнтів 1 групи: інфільтративний туберкульоз без засіву визначався лише у 2 групі: 11,4 \% проти 0 у 1, p<0,1; дисемінований туберкульоз легень порівняно частіше діагностували у 1 групі: 48,0 \% проти $25,7 \%, p<0,1$.

Висновки. У хворих на неефективно лікований вперше діагностований туберкульоз легень із наявністю стійкості до протитуберкульозних засобів, яких не включено до 4 категорії, порівняно із пацієнтами зі збереженою чутливістю до протитуберкульозних препаратів, відзначається більша тривалість інтоксикаційно-респіраторного синдрому в анамнезі до встановлення діагнозу. У таких хворих виявлено тенденцію до більш поширених уражень легень. За іншими клініко-рентгенологічними та бактеріологічними показниками статистично значимих відмінностей не виявлено.

КЛючОВІ СлОВА: туберкульоз; невдача лікування; стійкість до протитуберкульозних препаратів.

Вступ. 3 одного боку, погана прихильність до лікування, наявність стійкості до протитуберкульозних препаратів, супутні захворювання, які погіршують переносимість терапії зумовлюють невдачу лікування вперше діагностованого туберкульозу $[1,8,9]$, але з іншого - при наявності гарного комплаєнсу та при збереженні чутливості до антибіотиків також може бути низька ефективність лікування туберкульозу легень. Вважають, що це можливо у зв'язку із розвитком вторинного імунодефіциту, наявністю функціональних порушень органів і систем [2]. Виникнення стійкості до протитуберкульозних препаратів ускладнює перебіг захворювання через збільшення термінів лікування пацієнтів і гіршу переносимість протитуберкульозних антибіотиків 2 ряду $[3,5,7]$.

У попередніх роботах $[4,6]$ було розглянуто можливі причини неефективного лікування вперше діагностованого туберкульозу легень, питання переносимості протитуберкульозної хіміотерапії, але не вивчалися клінічні особливості неефективно лікованого туберкульозу легень із наявністю стійкості до протитуберкульозних препаратів, який не віднесено до 4 категорії.

Мета дослідження - визначити клінічні особливості неефективно лікованого вперше діагностованого туберкульозу легень при наявності стійкості до протитуберкульозних засобів.
Матеріал і методи дослідження. Виконано ретроспективний аналіз 60 історій хвороб пацієнТів, які лікувалися в КУ «Запорізький обласний протитуберкульозний клінічний диспансер" 3ОР з 01.01.2013 по 31.08.2015 р. з діагнозом «Невдача лікування" серед пацієнтів із ВДТБ. Пацієнтів поділили на 2 групи. До 1 групи увійшло 25 осіб, у яких була встановлена резистентність до протитуберкульозних препаратів, та які не належали до 4 категорії хворих. У групі було 20 чоловіків $(80,0 \%)$ і 5 жінок $(20,0 \%)$, середній вік пацієнтів складав $(46,8 \pm 1,6)$ років. До 2 групи увійшло 35 осіб, у яких зберігалася чутливість до всіх протитуберкульозних препаратів. Чоловіків у групі було 26 (74,3\%), жінок - 9 (25,7\%), середній вік складав $(45,1 \pm 2,0)$ років. Групи виявилися репрезентативними за віком і статтю.

Статистичну обробку інформації проводили з використанням статистичного пакета ліцензійної програми «STATISTICA $®$ for Windows 6.0» (Stat Soft Inc., № AXXR712 D833214FAN5). Статистичну значимість відмінностей між групами визначали за допомогою критерію "х-квадратів», при кількості випадків менше 20 додатково користувалися правкою Єтса.

Результати й обговорення. Серед пацієнтів 1 групи 14 осіб були жителями Запорізької області (56,0 \%), 11 - міста Запоріжжя, у 2 - групі 21 жи- 
Огляди літератури, оригінальні дослідження, погляд на проблему

тель області (60,0 \%) та 14 - міста Запоріжжя $(40,0 \%)$. Лише 1 хворий 1 групи (4,0 \%) і 2 - 2 $(5,7 \%)$ працювали. Переважна більшість пацієнтів були курцями (92,0 \% 1 групи; 88,6 \% - 2 групи), 10 хворих 1 групи (40,0 \%) і 13 - 2 (37,1 \%) зловживали алкоголем, 2 пацієнти 1 групи (8,0 \%) і 3 - 2 $(8,6 \%)$ споживали ін'єкційні наркотичні засоби. у місцях позбавлення волі у минулому перебували 7 осіб 1 групи (28,0 \%) і 7 - 2 (20,0\%).

Переважна більшість хворих виявлені при зверненні до лікаря: 18 пацієнтів 1 групи (72,0\%) і 28 - 2 (80,0\%), при профілактичному огляді туберкульоз було встановлено лише у 7 пацієнтів 1 групи (28,0 \%) та у 7 - 2 (20,0 \%). Контакт із хворими на туберкульоз мали по 8 пацієнтів обох груп.

Попередню флюорографію не виконували більше 2 років 17 (68,0\%) пацієнтів 1 групи та 22 (62,8 \%) - 2 групи. Це свідчить про низьку прихильність даного контингенту хворих до профілактичного обстеження.

За показником індексу маси тіла групи пацієнтів не відрізнялися між собою: $(19,8 \pm 0,4)$ од. 1 групи проти $(19,9 \pm 0,7)$ од. 2 групи, $\mathrm{p}<0,05$.

Тривалість інтоксикаційно-респіраторного синдрому у пацієнтів до моменту встановлення діагнозу визначали за показниками: кілька тижнів, кілька місяців, понад 3 місяці, невідомо. Невідомою була тривалість симптомів у 7 пацієнтів (36,0 \%) 1 групи та у 8 (22,9 \%) - 2 (переважно виявлені при профілактичному огляді). Статистично значимо частіше тривалість захворювання понад 3 місяці була у 1 групі пацієнтів: 18,7 \% проти 7,4 \% -у 2, $p<0,05$ (рис. 1).
Більшість пацієнтів у обох групах мали інфільтративний туберкульоз із засівом і дисемінований: $88,0 \%$ у 1 групі та 80,0 \% - у 2. Але інфільтративний туберкульоз без засіву визначався лише у 2 групі: 4 пацієнти $(11,4 \%)$ проти 0 у 1, р $<0,1$. Дисемінований туберкульоз легень статистично значимо частіше діагностували у 1 групі, порівняно із 2: 12 випадків (48,0 \%) проти 9 (25,7 \%), р<0,1. Інфільтративний туберкульоз із засівом, казеозна пневмонія, фіброзно-кавернозний туберкульоз легень майже однаково часто зустрічалися у групах хворих (рис. 2).

Деструкції у легенях виявлені у переважної більшості пацієнтів: у 24 хворих 1 групи $(96,0 \%)$ і у $34-2$ (97,1\%). За поширеністю та розмірами деструкцій обидві групи статистично значимо не відрізнялися (табл. 1).

Позалегеневі ураження були у 8 пацієнтів 1 групи (32,0 \%) і у $12-2$ (34,3 \%). Серед позалегеневих уражень у групах хворих діагностували: туберкульоз бронхів - у 4 хворих 1 групи та у $11-2$, туберкульоз гортані - у 1 хворого 1 групи та у 2 2, ексудативний плеврит - у 1 пацієнта 1 групи, туберкульоз внутрішньогрудних лімфатичних залоз -у 1 пацієнта 1 групи, у 1 хворого 2 групи було ураження туберкульозом бронхів і гортані.

Переважна більшість хворих були бактеріовиділювачами: 23 пацієнти 1 групи (92,0 \%) і $33-2$ (94,3\%). Масивне бактеріовиділення встановили у 19 хворих 1 групи (76,0\%) і у $26-2$ (74,3\%).

Серед 25 хворих 1 групи було 11 осіб з монорезистентністю (44,0 \%) та 14 - 3 полірезистентністю (56,0%). При виявленні монорезистентних штамів мікобактерій туберкульозу у 2 осіб встановлено стійкість до ізоніазиду (8,0 \%), у 8 - до

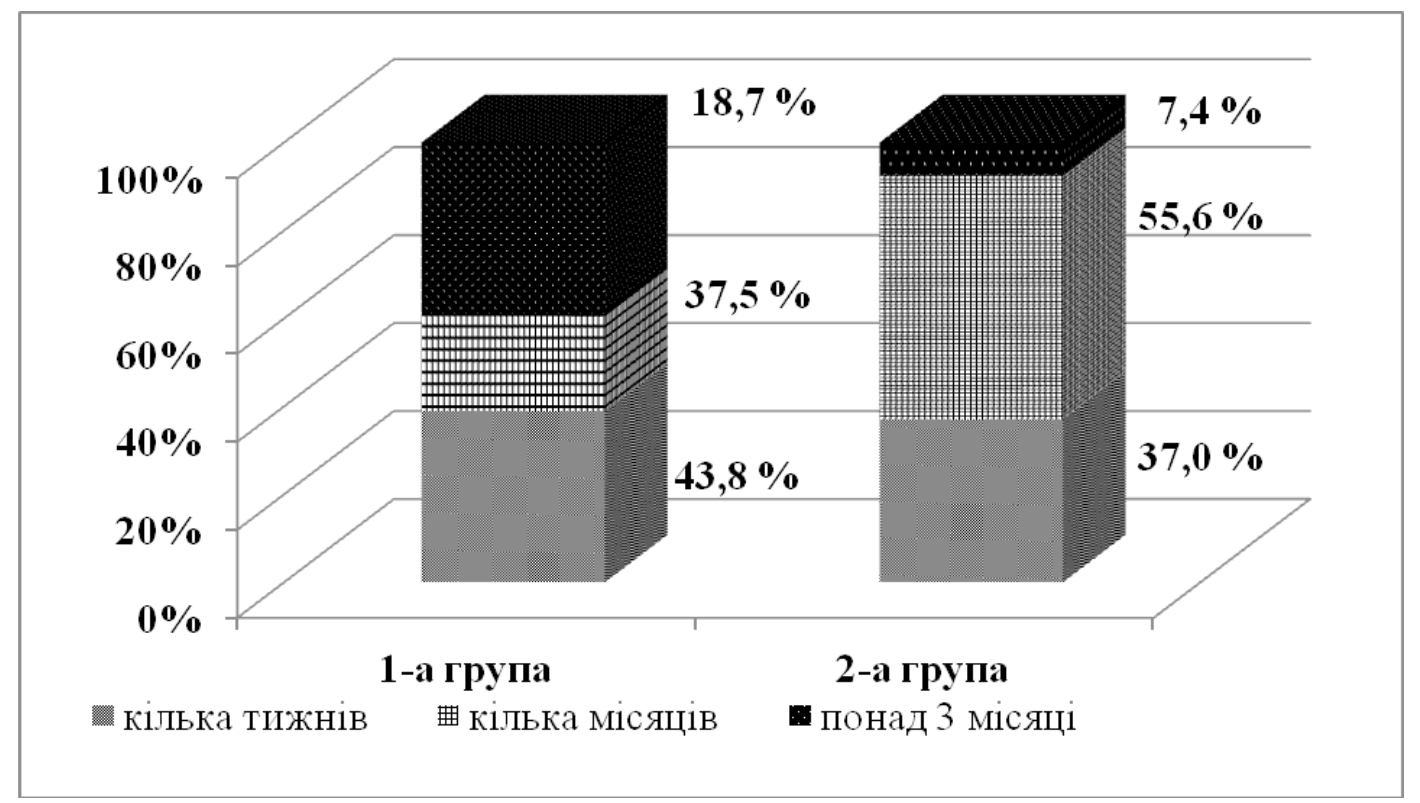

Рис. 1. Тривалість інтоксикаційно-респіраторного синдрому до моменту встановлення діагнозу у групах хворих. 


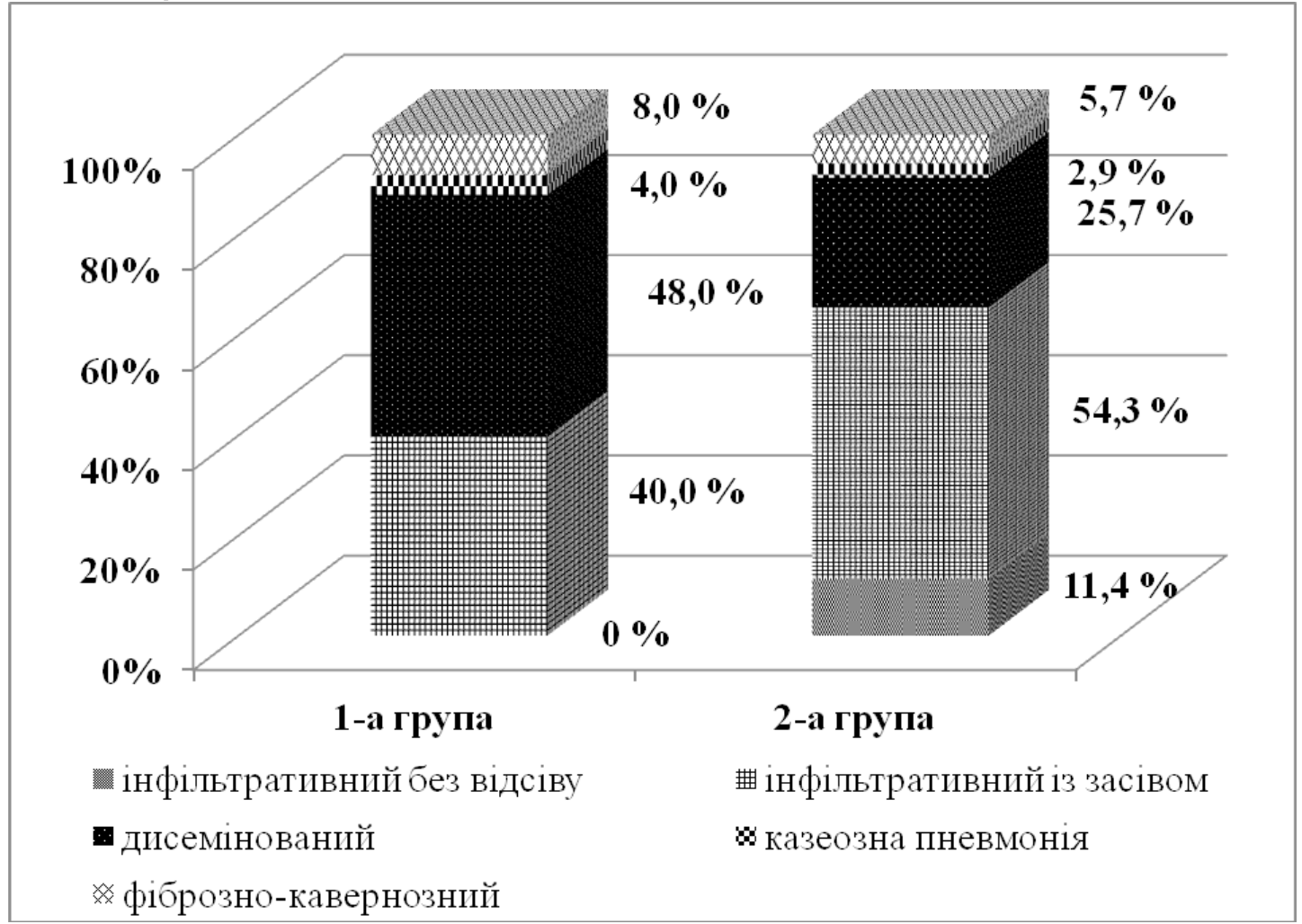

Рис. 2. Клінічні форми легеневого туберкульозу у групах хворих.

Таблиця 1. Поширеність, кількість і розміри деструкцій у групах хворих

\begin{tabular}{|c|c|c|c|c|c|}
\hline \multirow{2}{*}{ Показник } & \multicolumn{2}{|c|}{1 група } & \multicolumn{2}{|c|}{2 група } & \multirow{2}{*}{ р } \\
\cline { 2 - 5 } & а6с. & $\%$ & а6с. & $\%$ & $>0,05$ \\
\hline Всього & 24 & 96,0 & 34 & 97,1 & $>0,05$ \\
\hline Розміри $\leq 2$ см & 4 & 16,7 & 2 & 5,8 & $>0,05$ \\
\hline Розміри > с см & 8 & 33,3 & 12 & 35,3 & $>0,05$ \\
\hline Розміри > 3 см & 4 & 16,7 & 7 & 20,6 & $>0,05$ \\
\hline Розміри > 4 см & 2 & 8,3 & 4 & 11,8 & $>0,05$ \\
\hline Розміри > 5 см & 6 & 25,0 & 9 & 26,5 & $>0,05$ \\
\hline Дножинні деструкції & 3 & 12,5 & 8 & 23,5 & $>0,05$ \\
\hline
\end{tabular}

стрептоміцину (32,0 \%) та у 1 - до піразинаміду $(4,0 \%)$.

Серед полірезистентних штамів встановили такі комбінації стійкості до протитуберкульозних препаратів: ізоніазид+стрептоміцин - у 8 осіб $(32,0 \%)$, ізоніазид+стрептоміцин+етамбутол - у 3 осі6 (12,0\%), ізоніазид+стрептоміцин+піразинамід - у 1 особи (4,0 \%), ізоніазид+етіонамід - у 1 особи (4,0\%), ізоніазид+стрептоміцин+етамбутол+етіонамід - у 1 особи (4,0\%).

Висновки. У хворих на неефективно лікований вперше діагностований туберкульоз легень із наявністю стійкості до протитуберкульозних засобів, яких не включено до 4 категорії, порівняно із пацієн- тами зі збереженою чутливістю до протитуберкульозних препаратів, відзначається більша тривалість інтоксикаційно-респіраторного синдрому у анамнезі до встановлення діагнозу. У таких хворих виявлено тенденцію до більш поширених уражень легень. За іншими клініко-рентгенологічними та бактеріологічними показниками статистично значимих відмінностей не виявлено.

Перспективи подальших досліджень. В подальшому планується встановити ефективність лікування хворих на неефективно лікований вперше діагностований туберкульоз легень і визначити переносимість протитуберкульозної хіміотерапії. 


\section{ЛІТЕРАТУРА}

1. Ефективність лікування хворих на вперше діагностований туберкульоз та чинники, які погіршують їі в сучасних умовах / В. М. Мельник, І. О. Новожилова, В. Г. Матусевич, Л. В. Ареф`єва // Український пульмонологічний журнал. - 2008. - № 2. - С. 55-59.

2. Кузьмін М. М. Лікування хворих на вперше діагностований туберкульоз легень, ускладнений ренальною дисфункцією: автореф. дис. на здобуття наукового ступеня канд. мед. наук : спец. 14.01.26 «Фтизіатрія» / М. М. Кузьмін. - К., 2006. -23 с.

3. Мельник В.М. Хіміорезистентний туберкульоз: стан проблеми в Україні / В. М. Мельник, І. О. Новожилова, В. Г. Матусевич // Український медичний часопис. - 2013. - № 5 (97). - С. 43-45.

4. Побічні реакції у хворих на неефективно лікований вперше діагностований туберкульоз / Р. М. Шевченко, Ю. В. Просвєтов, Р. М. Ясінський, А. В. Левіч // Здобутки клінічної і експериментальної медицини. 2016. - № 3. - С. 96-99.

5. Хіміорезистентний туберкульоз: поширеність та профіль стійкості мікобактерій туберкульозу до антимікобактеріальних препаратів / В. М. Мельник,
І. О. Новожилова, В. Г. Матусевич [та ін.] // Український пульмонологічний журнал. - 2013. - № 3. - С. 19-23.

6. Ясінський Р. М. Визначення ризику невдачі лікування хворих на вперше діагностований туберкульоз легень / Р. М. Ясінський, Д. О. Васильков, А. В. Поволоцька // Буковинський медичний вісник. - 2016. - Т. 20, № 2 (78). - С. 178-182.

7. Alomar M. J. Factors affecting the development of adverse drug reactions (Review article) / M. J. Alomar // Saudi Pharmaceutical Journal. - 2014. - № 22. - P. 83-94.

8. Predictors of treatment failure among pulmonary tuberculosis patients in Mulago hospital, Uganda / E. Namukwaya, F. N. Nakwagala, F. Mulekya [et al.] // African Health Sciences. - 2011. - № 11. - P. 105-111.

9. Risk factors for tuberculosis treatment failure among pulmonary tuberculosis patients in four health regions of Burkina Faso, 2009: case control study [Electronic resource] / B. Sawadogo, K. S. Tint, M. Tshimanga [et al.] // Pan African Medical Journal. - 2015. - Vol. 21. Mode of access: http: // www.panafrican-med-journal.com/ content/article/21/152/full/\#.Vvh3eEO69qk.

\section{REFERENCES}

1. Miller, V.M., Novozhilov, I.A., Matusevich, V., \& Arefyeva, L.V. (2008). Efektyvnist likuvannia khvorykh na vpershe diahnostovanyi tuberkuloz ta chynnyky, yaki pohirshuiut yii v suchasnykh umovakh [The effectiveness of treatment first diagnosed with tuberculosis and factors that worsen it in modern terms]. Ukrainskyi pulmonolohichnyi zhurnal - Ukrainian Pulmonological Journal, 2, 55-59 [in Ukrainian].

2. Kuzmin, N.N. (2006). Likuvannia khvorykh na vpershe diahnostovanyi tuberkuloz lehen, uskladnenyi renalnoiu dysfunktsiieiu [Treatment of patients with newly diagnosed pulmonary tuberculosis complicated by renal dysfunction]. Extended abstract of candidate's thesis. Kyiv: Ftiziatriia [in Ukrainian].

3. Miller, V.M., Novozhilov, I.A., Matusevich, V. (2013). Khimiorezystentnyi tuberkuloz: stan problemy v Ukraini [Chemioresistent tuberculosis: the state of the problem in Ukraine]. Ukrainskyi medychnyi zhurnal - Ukrainian Medical Journal, 5 (97), 43-45 [in Ukrainian].

4. Shevchenko, R.M., Prosvyetov, Y., Yasinskyi, R.M., Levich, A.V. (2016). Pobichni reaktsii u khvorykh na neefektyvno likovanyi vpershe diahnostovanyi tuberkuloz [Adverse reactions in patients treated ineffectively first diagnosed TB]. Zdobutky klinichnoi ta eksperymentalnoi medytsyny - Achievements of Clinical and Experimental Medicine, 3, 96-99 [in Ukrainian].

5 Miller, V.M., Novozhilov, I.A., Matusevich, V.
(2013). Khimiorezystentnyi tuberkuloz: poshyrenist ta profil stiykosti mikobakteriy tuberkulozu do antymikobakterialnykh preparativ [Chemioresistant tuberculosis: prevalence and profile of Mycobacterium tuberculosis resistance to antimycobacterial drugs]. Ukrainskyi pulmonolohichnyi zhurnal - Ukrainian Pulmonological Journal, 3, 19-23 [in Ukrainian].

6. Yasinskyi, R.M., Vasylkov, D.O., Povolotska, A.V. (2016). Vyznachennia ryzyku nevdachi likuvannia khvorykh na vpershe diahnostovanyi tuberkuloz lehen [The definition of risk treatment failure patients with newly diagnosed pulmonary tuberculosis]. Bukovynskyi medychnyi zhurnal Bukovynian Medical Journal, 2 (78), 178-182 [in Ukrainian].

7. Alomar, M.J. (2014). Factors affecting the development of adverse drug reactions (Review article). Saudi Pharmaceutical Journal, 22, 83-94.

8. Namukwaya, E., Nakwagala, F.N., \& Mulekya, F. (2011). Predictors of treatment failure among pulmonary tuberculosis patients in Mulago hospital, Uganda. African Health Sciences, 11, 105-111.

9. Sawadogo, B., Tint, K.S., \& Tshimanga, M. (2015). Risk factors for tuberculosis treatment failure among pulmonary tuberculosis patients in four health regions of Burkina Faso, 2009: case control study [Electronic resource]. Pan African Medical Journal, 21. Mode of access: http: // www.panafrican-med-journal.com/content/ article/21/152/full /\#.Vvh3eEO69qk. 


\title{
Огляди літератури, оригінальні дослідження, погляд на проблему \\ КЛИНИЧЕСКИЕ ОСОБЕННОСТИ НЕЭФФЕКТИВНО ЛЕЧЕННОГО ВПЕРВЫЕ ДИАГНОСТИРОВАННОГО ТУБЕРКУЛЕЗА ЛЕГКИХ С НАЛИЧИЕМ УСТОЙЧИВОСТИ К ПРОТИВОТУБЕРКУЛЕЗНЫМ ПРЕПАРАТАМ
}

\author{
ОР. М. Ясинский ${ }^{1}$, А. М. Красневич ${ }^{2}$ \\ 1 Запорожский государственный медицинский университет \\ ${ }^{2}$ КУ Городской противотуберкулезный диспансер № 4 ЗОС
}

РЕЗЮМЕ. Целью исследования стало установление клинических особенностей неэффективно леченого впервые диагностированного туберкулеза легких при наличии устойчивости к противотуберкулезным средствам.

Материал и методы. Для достижения цели проанализированы 60 историй болезней пациентов. Больные были поделены на 2 группы: в 1 группу вошли 25 человек, у которых была установлена резистентность к противотуберкулезным препаратам, и которые не принадлежали к 4 категории больных, во 2 группу вошли 35 человек, у которых сохранилась чувствительность ко всем противотуберкулезным препаратам. Определяли статистическую значимость различий между группами с помощью критерия "х-квадратов", при количестве случаев менее 20 дополнительно пользовались правкой Етса.

Результаты. Длительность заболевания до установления диагноза туберкулеза составила у 18,7 \% 6ольных 1 группы и 7,4 \% - 2 группы более 3 месяцев, p<0,05. Определялась тенденция к более распространенным формам туберкулеза у пациентов 1 группы: инфильтративный туберкулез без посева определялся только во 2 группе: 11,4 \% против 0 в 1, р<0,1; диссеминированный туберкулез легких сравнительно чаще диагностировали в 1 группе: $48,0 \%$ против $25,7 \%, p<0,1$.

Выводы. У больных неэффективно леченным впервые диагностированным туберкулезом легких с наличием устойчивости к противотуберкулезным средствам, который не включен в 4 категорию, по сравнению с пациентами с сохраненной чувствительностью к противотуберкулезным препаратам, отмечается большая продолжительность интоксикационно-респираторного синдрома в анамнезе к моменту установления диагноза. у таких больных выявлена тенденция к более распространенным поражениям легких. По другим клиникорентгенологическим и бактериологическим показателям статистически значимых различий не выявлено.

КЛючЕВЫЕ СЛОВА: туберкулез; неудача лечения; устойчивость к противотуберкулезным препаратам.

\section{CLINICAL FEATURES OF NEWLY DIAGNOSED PULMONARY TUBERCULOSIS TREATMENT FAILURE WITH THE PRESENCE OF RESISTANCE TO ANTITUBERCULOUS DRUGS}

\author{
@R. M. Yasinskyi', A. M. Krasnevich² \\ 'Zaporizhian State Medical University \\ ${ }^{2}$ Zaporizhian TB Dispensary № 4
}

SUMMARY. The aim of the study was to establish the clinical features of newly diagnosed pulmonary tuberculosis treatment failure in the presence of resistance to TB drugs. To achieve the aim we analyzed 60 cases of patients. Patients were divided into 2 groups: the group 1 included 25 people who established resistance to TB drugs, and those not belonging to category 4, group 2 of patients included 35 people who had sensitivity of TB drugs. We determined the statistical significance of differences between groups using the criterion of "x-squared", while the number of cases that used less than 20 we additional used Yates` correction.

Results and Discussion. The duration of intoxication and respiratory syndrome over 3 months before tuberculosis diagnosing was $18.7 \%$ in the group 1 and in $7.4 \%$ in the group $2, p<0.05$. The tendency to more widespread forms of tuberculosis was determined in the group 1 of patients: infiltrative tuberculosis without seeding defined only in the group 2: $11.4 \%$ and 0 in the group 1, p<0.1; disseminated tuberculosis diagnosed more often in group 1 compared with the group 1: $48.0 \%$ and $25.7 \%, p<0.1$.

Conclusions. In patients with newly diagnosed pulmonary tuberculosis treatment failure with the presence of resistance to TB drugs, which are not included to the four category compared with patients with sensitivity to TB drugs longer duration of intoxication and respiratory syndrome in anamnesis before diagnosing was observed. Tendency to more widespread lung lesions was determined in these patients. According to other clinical-radiological and bacteriological parameters statistically significant differences were not found.

KEY WORDS: tuberculosis; treatment failure; resistance to TB drugs. 